\title{
SUKOB INTERESA ČLANOVA UPRAVE SPORTSKOG DIONIČKOG DRUŠTVA
}

\author{
UDK: 343. 35: $347: 725$
}

Primljeno: 02. II. 2018.

Pregledni rad

\begin{abstract}
U radu se obrađuje pitanje sukoba interesa članova uprave sportskog dioničkog društva. Raspravlja se o širem kontekstu problematike sukoba interesa. Tako se razmatraju odredbe Zakona o sportu te posebice odgovarajuće odredbe Zakona o trgovačkim društvima kojima je uređeno to područje. Pitanje sukoba interesa usko je povezano s odredbama o zabrani sklapanja ugovora sa samim sobom, o zabrani konkurencije, o odobrenju kredita članovima uprave, o dužnosti uprave da vodi poslove društva kao uredan i savjestan gospodarstvenik, ali je u prvom redu uređeno odredbom o sukobu interesa koja je u Zakon o trgovačkim društvima unesena izmjenom tog Zakona iz 2015. godine. Sukob interesa analizira se posebno u kontekstu preporuka našeg Kodeksa korporativnog upravljanja čija je najnovija verzija stupila na snagu 6. I. 2018. godine, a čija dobrovoljna primjena od strane sportskih dioničkih društava ima smisla jer takva društva imaju veliki značaj za lokalnu zajednicu, a i mnogo šire. To se pokazalo i na međunarodnom planu jer sportski klubovi koji su ustrojeni kao dionička društva prihvaćaju pravila „dobrog upravljanja“. Raspravlja se i o pojmu „,interesa društva“ koji treba razlikovati od interesa većinskog dioničara, ali svakako i od privatnih, osobnih interesa članova uprave.
\end{abstract}

Ključne riječi: sportsko dioničko društvo, uprava, sukob interesa, zabrana konkurencije, kodeks korporativnog upravljanja

\section{UVOD}

Sport i sportska natjecanja predstavljaju važnu gospodarsku djelatnost, a sportski klubovi postaju poduzetnički pothvati čije se vođenje više ne može prepustiti samo zaljubljenicima već to moraju biti osobe koje posjeduju potrebna znanja i vještine. Ipak, tu nije riječ o bilo kakvom pothvatu. Posebnost gospodarskog položaja sportskih klubova počiva na dvjema važnim značajkama.

Prvo, sportske lige i klubovi koji u njima sudjeluju stvaraju zajednički proizvod čija vrijednost ovisi o učinkovitoj suradnji između klubova koji se natječu. Klubovi pristaju sudjelovati u natjecanju te prihvaćaju pravila natjecanja jer sudjelovanje u stvaranju zajedničkog proizvoda dovodi do rasta ekonomske vrijednosti onih proizvoda koji svaki klub stvara i pojedinačno. Ekonomski rezultat cijelog sportskog natjecanja (lige i njezinih članova - klubova) bit će maksimalan kada 
postoji određeni stupanj ravnoteže - izjednačenosti klubova po kvaliteti - što onda ishod samog natjecanja čini neizvjesnim i time zanimljivim za gledatelje. ${ }^{1}$

Druga posebnost sporta kao gospodarske djelatnosti jest postojanje kontinuiranog napora za postizanjem odgovarajuće ravnoteže između zahtjeva financijske održivosti kluba s jedne te zahtjeva za što bržim ostvarenjem sportskog uspjeha s druge strane. Spomenuti zahtjev za sportskim uspjehom navodi klubove da ulažu znatna sredstva tj. da riskiraju kako bi ostvarili sportski uspjeh. Sredstva se ulažu za poboljšanje infrastrukture, ali ponajviše za transfere igrača koje uz to treba privući odnosno zadržati i visokim primanjima. Na streloviti rast primanja sportaša, barem onih koji sudjeluju u najpopularnijim sportovima odnosno klupskim natjecanjima, utječe i porast iznosa novčanih sredstava koje klubovi dobivaju s naslova prava na televizijsko emitiranje sportskih susreta. To je zasigurno jedan od najvažnijih razloga zbog kojega mnogi profesionalni sportski klubovi, kad se podvuče crta, i ne ostvaruju dobit jer neprestano vlada pritisak da se sva slobodna sredstva ulože, a sve u cilju ostvarenja sportskog uspjeha. U ekstremnim slučajevima takav način rada može dovesti do propasti sportskog kluba jer uprave klubova u traganju za uspjehom zanemaruju interese samog kluba, njegovih vjerovnika te članova udruge odnosno dioničara pa postaje jasno da s povećanom pozornošću treba pratiti rad osoba koje u njima vode poslove. Zbog prirode sportskog natjecanja, procjena o ulaganju uvijek nosi rizike koji bi u nekoj drugoj grani poslovanja bili ocijenjeni nerazumno visokima, praktički hazardnima. Tom stanju zasigurno ne pomaže niti činjenica da osobe ovlaštene za vođenje poslova i zastupanje tih klubova nerijetko i ne posjeduju dostatna znanja niti vještine za uspješno obavljanje te funkcije ili su pak spremni na nerazumno visoke rizike jer u slučaju neuspjeha neće osobno, svojom imovinom, odgovarati za nagomilane obveze.

Posebnost sportskog natjecanja kao gospodarske djelatnosti ogleda se i u svezi $s$ tržištem rada gdje se postavlja pitanje pravnog položaja igrača, ali i njihove knjigovodstvene evidencije. U smislu bilance, igrači predstavljaju dugotrajnu nematerijalnu imovinu, ali ujedno predstavljaju daleko najvažniju stavku poslovnih prihoda kluba.

Zbog svega navedenog, postaje jasno da pitanje poslovodstva i zastupanja sportskih klubova postaje ključno za njihov daljnji razvoj i uspjeh. Ako je sportski klub ustrojen kao dioničko društvo, onda će tu funkciju obnašati njegova uprava. U radu svake one osobe kojoj je povjereno upravljanje tuđom imovinom i općenito skrb o tuđim interesima, može nastati neki od slučajeva koje svrstavamo pod zajednički pojam ,sukob interesa“.

Pregledom različitih propisa postaje jasno da Zakonodavac ne daje sveobuhvatnu definiciju tog fenomena već najčešće primjerno navodi slučajeve odnosno okolnosti kod kojih je riječ o sukobu interesa. ${ }^{2}$ Jasno je da naš Zakonodavac nastoji uskladiti

Tako Michie, J./ Oughton, C., „The Corporate Governance of Professional Football Clubs in England“", Corporate Governance: An International Review, Vol. 13, br. 4, 2005, str. 1.

2 Detaljnije o tome v. Bačić, A., Sukob interesa i pitanje odgovornosti u ustavnoj demokraciji, Rad Hrvat. akad. znan. i umjet. Razred za druš. znan. 49=512(2012) : 177-202. Autor na str. 178. navodi da 
pravni i institucionalni okvir sprečavanja sukoba interesa sa standardima koji vrijede u ostalim državama članicama Europske unije. Tako se, primjerice, u Zakonu o sprečavanju sukoba interesa (Narodne novine 26/2011, 12/2012, 126/2012, 57/2015) navodi da je svrha tog propisa sprečavanje sukoba interesa u obnašanju javnih dužnosti, sprečavanje privatnih utjecaja na donošenje odluka u obnašanju javnih dužnosti, jačanje integriteta, objektivnosti, nepristranosti i transparentnosti u obnašanju javnih dužnosti te jačanje povjerenja građana u tijela javne vlasti. $U$ obnašanju javne dužnosti dužnosnici ne smiju svoj privatni interes stavljati iznad javnog interesa. Sukob interesa postoji kada su privatni interesi dužnosnika u suprotnosti s javnim interesom, a posebice kada privatni interes dužnosnika utječe na njegovu nepristranost u obavljanju javne dužnosti ili se osnovano može smatrati da privatni interes dužnosnika utječe na njegovu nepristranost u obavljanju javne dužnosti ili privatni interes dužnosnika može utjecati na njegovu nepristranost $\mathrm{u}$ obavljanju javne dužnosti (vidi čl. 1. i 2. Zakona).

Odredbe koje uređuju pitanje sukoba interesa nalazimo i u Zakonu o tržištu kapitala, ${ }^{3}$ Zakonu o javnoj nabavi, Zakonu o kreditnim institucijama i brojnim drugim propisima.

Predmet rada jest sukob interesa članova uprave sportskog dioničkog društva pa će u nastavku rada o tome biti više riječi.

\section{SUKOB INTERESA ČLANOVA UPRAVE SPORTSKOG DIONIČKOG DRUŠTVA PREMA ZAKONU O SPORTU}

Zakon o sportu na nekoliko mjesta uređuje pitanje sukoba interesa članova uprave sportskog dioničkog društva. Tako se, primjerice, odredbom čl. 38. spomenutog Zakona uređuje da uz osobe koje ne mogu biti članovi uprave ili nadzornog odbora dioničkog društva, prema odredbama Zakona o trgovačkim društvima i Zakona o sprečavanju sukoba interesa u obnašanju javnih dužnosti, članovi uprave i nadzornog odbora s.d.d.-a ne mogu biti niti osobe:

- koje su članovi sportskih klubova-udruga za natjecanje istoga sporta,

- koje su dioničari s.d.d.-a istoga sporta,

- koje su članovi tijela, osobe ovlaštene za zastupanje te osobe ovlaštene za vođenje poslova po odluci ovlaštenog tijela ili na temelju općih akta sportskog kluba - udruge za natjecanje istoga sporta,

- koje su članovi tijela s.d.d.-a istoga sporta,

je u suvremenoj ustavnopravnoj i politološkoj literaturi već odavno stvoren konsenzus da je „upravljanje konfliktom interesa" od kritičnog značaja za sprečavanje korupcije.

Tako je, između ostalog, u čl. 53. st. 1. spomenutog Zakona (Narodne novine 88/2008, 146/2008, $74 / 2009,54 / 2013,159 / 2013,18 / 2015,110 / 2015,123 / 2016,131 / 2017)$ uređena dužnost investicijskog društva da uspostavi mehanizme, mjere i postupke za utvrđivanje i sprečavanje sukoba interesa. 
- koje svojim djelovanjem mogu neposredno utjecati na sustav natjecanja u odgovarajućem sportu, a osobito sportaši, menadžeri u sportu, kao i osobe koje su to bile u razdoblju od posljednjih godinu dana,

- članovi pravnih osoba koje obavljaju djelatnost organiziranja sportskih kladionica, kao i osobe koje su to bile posljednje tri godine,

- koje s menadžerima u sportu i članovima pravnih osoba te članovima tijela pravnih osoba koje obavljaju djelatnost organiziranja sportskih kladionica djeluju zajednički.

Nadalje, i čl. 39. Zakona o sportu uređuje pitanje sukoba interesa članova uprave jer predviđa dužnost sportskog dioničkog društva na redovito i pravovremeno slanje obavijesti Povjerenstvu za profesionalne sportske klubove i nacionalnom sportskom savezu o svim važnijim poslovnim događajima, a osobito o ugovorima koje s.d.d. sklapa s članovima uprave i nadzornog odbora s.d.d.-a, osim ugovora o obavljanju poslova članova uprave odnosno nadzornog odbora za s.d.d.

Neizravno se iz odredbe čl. 34. st. 3. Zakona o sportu kojom se utvrđuje krug povezanih osoba kod stjecanja dionica može zaključiti da spomenuti Zakon prepoznaje mogući utjecaj i sukob interesa u svezi sa srodstvom jer vrijedi pretpostavka da fizičke osobe djeluju zajednički ako su u krvnom srodstvu (preci i potomci), braća i sestre i njihovi potomci, ako su bračni ili izvanbračni drugovi te ako su u odnosu posvojitelj-posvojenik.

\section{SUKOB INTERESA ČLANOVA UPRAVE SPORTSKOG D. D.-A PREMA ODREDBAMA ZTD-A}

Zakon o trgovačkim društvima na više mjesta uređuje pitanje sukoba interesa i, barem teoretski, svi se ti slučajevi mogu pojaviti i u kontekstu sportskih dioničkih društava. Uprava svakog dioničkog društva, pa i onog sportskog, vodi poslove društva na vlastitu odgovornost, primjenjujući pri tome pozornost urednog i savjesnog gospodarstvenika te je dužna čuvati poslovnu tajnu društva. ${ }^{4} \mathrm{Kod}$ donošenja poduzetničke odluke, uprava ima pravo na (slobodnu) poslovnu prosudbu, a koje pravilo je sadržano u odredbi da član uprave ne postupa protivno obvezi o načinu vođenja poslova društva ako pri donošenju poduzetničke odluke smije na temelju primjerenih informacija razumno pretpostaviti da djeluje za dobrobit društva (čl. 252. st. 1. ZTD-a). Iz toga proizlazi da tu nije riječ o postupanju za koje postoji zakonska obveza (npr. dužnost plaćanja poreza) niti je riječ o obvezi koja bi za upravu proizlazila iz društvenog ugovora. Nadalje, uprava mora raspolagati s primjerenom informacijom što utvrđujemo prema konkretnim okolnostima u vrijeme poduzimanja posla. ${ }^{5} \mathrm{U}$ tom smislu, nije nužno da se ispitaju baš sve mogućnosti i rizici. Tako će donošenju odluke o stjecanju udjela u nekom društvu

4 Usp. Barbić, J., Pravo društava: dioničko društvo, Organizator, Zagreb, 2010., str. 790. i dalje.

5 Vidi Spindler, G. u: Goette, W./Habersack, M., Münchener Kommentar zum Aktiengesetz, 4. Auflage, Verlag C.H. Beck München, 2014., § 93, Rn. 75. 
prethoditi provjera Due Diligence, a kod odluke o kupnji neke opreme za obavljanje predmeta poslovanja bit će u pravilu dostatno prikupiti nekoliko ponuda. Uprava u svakom slučaju mora postupati u dobroj vjeri (,,.. razumno pretpostaviti da djeluje za dobrobit društva"). Vidljivo je da navedena odredba uređuje pitanje sukoba interesa jer postupanje za dobrobit društva znači dužnost uprave da stavi u prvi plan interes društva te da zanemari svoj privatni interes. Pojam dobrobiti ili interesa društva ponekad se izjednačava s ciljem društva. U svakom slučaju, nema mjesta zaključku da dioničko društvo ima samostalan interes koji je potpuno različit od interesa dioničara već bi ispravan zaključak bio da je interes društva rezultanta interesa svih dioničara. ${ }^{6}$ Točno je i to da je uprava organ koji daje procjenu o tome što je u konkretnom slučaju interes društva. Međutim, ako član uprave društva ima privatni interes koji je različit od interesa društva, jasno je da tu nema mjesta primjeni pravila poslovne prosudbe.

Sukob interesa uređen je i odredbama o zabrani konkurencije (čl. 248. ZTD-a). Član uprave ne može bez suglasnosti nadzornog odbora za svoj ni za tuđi račun obavljati poslove koji ulaze u predmet poslovanja društva, ne može biti član uprave ni nadzornog odbora u drugome društvu koje se bavi poslovima iz predmeta poslovanja društva, a ne može ni u prostorijama društva obavljati poslove za svoj niti za tuđi račun. Bez te suglasnosti član uprave ne može biti ni član trgovačkoga društva koji osobno odgovara za obveze toga društva, ako se ono bavi poslovima iz predmeta poslovanja društva. ${ }^{7}$

Autonomnim aktima društva kao i menadžerskim ugovorom moguće je isključiti, ublažiti, ali i pooštriti odredbu o zabrani konkurencije. Tako se, primjerice, može suziti krug zabranjenih ponašanja ili odrediti posebne pretpostavke za isključenje ili ublažavanje zabrane. U menadžerskom ugovoru može se precizno navesti podatak u čemu se točno sastoji zabranjeno ponašanje te se može taksativno navesti za koje poslove vrijedi zabrana konkurencije. Nadalje, statutom je moguće odrediti dodatne pretpostavke koje moraju biti ispunjene da bi nadzorni odbor uopće smio dati suglasnost za obavljanje nekog posla, a statutom je dopustivo i isključiti mogućnost dobivanja suglasnosti nadzornog odbora.

Postupi li član uprave suprotno zabrani konkurencije, društvo može od njega tražiti:

- da mu nadoknadi time pričinjenu štetu ili,

- da dopusti da se poslovi koje je sklopio za svoj račun smatraju poslovima sklopljenim za račun društva, a da iz poslova koje je sklopio za tuđi račun prenese društvu ono što je za to primio, odnosno da mu ustupi zahtjev za naplatu onoga što bi trebalo da primi. Zastara nastupa u subjektivnom roku od $3 \mathrm{mj}$. od saznanja odnosno u objektivnom roku od 5. g. od počinjenja radnje koja predstavlja kršenje spomenute zabrane.

6 Tako Hölters, W., Aktiengesetz, 3. Auflage, Vahlen, München, 2017., § 93, Rn. 142.

7 Usp. Gorenc, V., u: Gorenc et al., Komentar Zakona o trgovačkim društvima, RRiF, Zagreb, 2008., str. 475. i dalje. 
Nema prepreke da se za slučaj kršenja zabrane konkurencije kao sankcija predvidi obveza člana uprave na plaćanje ugovorne kazne ili umanjenje naknade za rad. ${ }^{8}$ Istekom mandata član uprave više nije vezan zabranom konkurencije. Međutim, menadžerskim ugovorom može se urediti da se zabrana konkurencije proteže i na određeno razdoblje nakon što je članu uprave istekao mandat. To je akt privatne stranačke autonomije koji, doduše, mora ispuniti zahtjev da nije suprotan načelu savjesnosti i poštenja. ${ }^{9}$ Pokazalo se u praksi da je taj zahtjev ispunjen ako to dodatno razdoblje zabrane konkurencije nije dulje od dvije godine, zabrana je prostorno ograničena i/ili kad je takvo ugovaranje opravdano zbog zaštite opravdanih interesa društva, a ako uz to bivši član uprave ostvaruje i pravo na naknadu zbog toga što propušta poduzimati radnje kojima bi konkurirao svom (bivšem) društvu. Ako se takvim sporazumom samo štiti pravo raspolaganja informacijama o poslovnoj klijenteli odnosno pravo na raspolaganje bazama podataka o potrošačima, nije potrebno dati naknadu bivšem članu uprave.

Pitanjem sukoba interesa bavi se i odredba kojom je uređeno davanje kredita članovima uprave (čl. 249. ZTD-a). Tako društvo može dati kredit članovima uprave i članovima njihovih užih obitelji samo na temelju odluke nadzornog odbora koja se ne može donijeti generalno već se može odnositi samo na određene ugovore o kreditu. Nadalje, takav ugovor o kreditu mora se sklopiti najkasnije tri mjeseca od dana donošenja odluke kojom se kredit odobrava. Vrijedi tu pripomenuti da se kreditom smatraju i druge pravne radnje koje se u gospodarskome smislu mogu s njime izjednačiti. Primjerice, ako društvo (uprava) donese odluku da će nekim članovima uprave snositi troškove smještaja, tu je riječ o pravnoj radnji koja se može izjednačiti s davanjem kredita pa je za tu odluku nadležan nadzorni odbor. Nema prepreke da odluku o odobrenju kredita nadzorni odbor donese i naknadno. No ako je takva (i naknadna) odluka izostala, član uprave dužan je vratiti kredit odmah. Ako je član uprave pri tome povrijedio svoju dužnost iz čl. 252. ZTD-a, bez obzira na naknadno odobrenje tog posla, društvo prema tom članu uprave zadržava pravo na naknadu štete. Šutnja ne znači da je nadzorni odbor dao pristanak. To jasno proizlazi i iz činjenice da se odluka donosi za točno određene ugovore o kreditu. Vidljivo je da se ovom odredbom htjelo spriječiti da uprava sama, bez ikakve kontrole, odlučuje o davanju kredita svojim članovima. ${ }^{10}$ Odredba je prisilne naravi i stoga nije dopušteno njezino ublažavanje, primjerice društvenim ugovorom ili poslovnikom o radu uprave. S druge strane, dopustivo je dodatno postrožiti uvjete za odobrenje kredita članovima uprave. ${ }^{11}$ Također je dopustivo da nadzorni odbor donošenje odluke prepusti nekom gremiju u društvu, ali donošenje odluke ne smije 88 Rn. 10.

8 Vidi Koch, J., u: Hüffer, U./Koch, J., Aktiengesetz, Verlag C.H. Beck München, 12. Aufl. 2016., §

9 Vidi čl. 4. ZOO-a (Narodne novine 35/2005, 125/2011, 78/2015). Detaljnije o tome v. Gorenc, V., u: Gorenc et al., Komentar Zakona o obveznim odnosima, Narodne novine, Zagreb, 2014., str. 11.-13.

10 Međutim, kod davanja kredita članovima nadzornog odbora odobrenje daje nadzorni odbor. Vidi čl. 271. ZTD-a.

11 Usp. Schwennicke, A., u: Grigoleit, H. C., Aktiengesetz, 1. Auflage, Verlag C.H. Beck München, 2013., § 89, Rn. 1.-23. 
prepustiti primjerice jednom od svojih članova. U svezi s davanjem kredita, logičan je i zaključak da takvi pravni poslovi ne smiju znatnije odstupati od sličnih ugovora koji se sklapaju prema uobičajenim (tržišnim) uvjetima.

U odredbe kojima se u Zakonu uređuje sukob interesa spada i ona o sklapanju ugovora sa samim sobom (čl. 49. u svezi s čl. 41. st. 3. ZTD-a). Tu je riječ o tipičnom slučaju sukoba interesa. Član uprave ne može bez posebne ovlasti društva nastupati kao druga ugovorna strana i s društvom sklapati ugovore u svoje ime i za svoj račun, u svoje ime a za račun drugih osoba (kao komisionar) ili u ime i za račun drugih osoba (zastupnik). ${ }^{12}$ Članu uprave sportskog dioničkog društva ovlast daje nadzorni odbor, a s obzirom na okolnost da Zakonodavac izričito navodi da je riječ o posebnoj ovlasti, tada se ona ne može dati u formi opće punomoći niti se takva ovlast može dati prešutno, ali se zato može dati naknadno uz precizan opis pravnog posla za koji se daje.

Nadalje, već spominjana dužna pozornost uprave uključuje i dužnost članova tog organa na lojalno postupanje prema društvu i dioničarima što također predstavlja pravilo kojim se uređuje pitanje sukoba interesa. $\mathrm{S}$ jedne strane, članovi uprave dužni su izbjeći sukob interesa kad god je to moguće, a ako je sukob interesa u konkretnom slučaju neizbježan, dužni su o tome obavijestiti ostale članove uprave i nadzorni odbor. Dužnost obavještavanja o postojanju sukoba interesa uključuje i dužnost da se nadzornom odboru omogući da provede odgovarajuću kontrolu (ispitivanje) svih okolnosti konkretnog slučaja, a član uprave im mora pružiti sve informacije od značaja za donošenje odluke (čl. 248.a ZTD-a). Na ovom mjestu vrijedi pripomenuti da nigdje nije propisano kakva mora biti odluka nadzornog odbora već se samo propisuje dužnost člana uprave na obavještavanje o sukobu interesa. Dužnost na lojalno postupanje nadopunjena je i zabranom članovima uprave da stječu posebne povlastice ili koristi od društva osim kada je to izrijekom dopušteno (zabrana korupcije).

Iz dužnosti na lojalno ponašanje proizlazi i zabrana članovima uprave da iskoriste za sebe poslovne šanse koje pripadaju društvu. Prema tom polazištu, koje je detaljno razrađeno u američkom pravu (Corporate Opportunity), ${ }^{13}$ uprava je povrijedila svoju dužnost kad u svoje ime i za svoj račun poduzme pravni posao koji spada u predmet poslovanja društva, a koji bi društvo moglo uspješno i samo sklopiti ili taj posao već prema svim okolnostima ,pripada“ društvu. Može se iz toga zaključiti da je poviše opisana zabrana konkurencije viši rodni pojam u odnosu na zabranu prisvajanja poslovnih šansi jer ova prva djeluje kao preventivna zaštita dok se druga zabrana odnosi na konkretne zahvate u sferi poslovanja društva. Stoga se tu primjenjuju odredbe o zabrani konkurencije. Zabrana prisvajanja poslovnih šansi obuhvaća samo one poslove koji nedvojbeno spadaju u područje djelatnosti društva. Formalni kriterij koji mora biti ispunjen jest taj da je član uprave za poslovnu šansu

12 Usp. Barbić, J., Pravo društava: opći dio, Organizator, Zagreb, 2006., str. 485. i dalje.

13 Detaljnije o tome vidi primjerice kod Struan, S., „The Corporate Opportunity Doctrine and Impossibility Arguments“, Modern Law Review, Vol. 66, Issue 6 (2003.), str. 852. i dalje. 
saznao dok je postupao kao član uprave društva. To će, primjerice, biti slučaj kada je društvo zaprimilo ponudu za sklapanje ugovora, ako je društvo već stupilo u pregovore s trećim osobama ili se u društvu već raspravljalo o sklapanju ugovora, ako je primjerice usvojen zaključak da treba sklapati poslove iz određene gospodarske grane ili ako je društvo iskazalo interes za sklapanje takvih poslova.

Dvojbeno je kako promatrati situaciju kad je poslovna moguénost u vidu poslovne ponude upućena članu uprave privatnim putem. Ako posao spada u predmet poslovanja društva te je u skladu s poslovnom politikom društva, tada nije od značaja okolnost kako je član uprave saznao za tu mogućnost - na privatnoj rođendanskoj zabavi ili na poslovnom sastanku. Dužnost na lojalno ponašanje članova uprave postoji i izvan radnog vremena pa stoga nije od značaja okolnost da je član uprave do neke informacije došao privatnim kanalima. Jedini izuzetak predstavljaju slučajevi kada je očito da je poslovna ponuda članu uprave poslana iz razloga koji su strogo osobne prirode. Član uprave ne može uputiti prigovor da društvo ionako nema potrebna sredstva za sklapanje nekog posla. Uprava tu mora postupati s pozornošću urednog i savjesnog gospodarstvenika te je, prema okolnostima slučaja, dužna pribaviti kapital potreban za ostvarenje takvog posla. Prethodno je član uprave dužan o svemu informirati ostale članove uprave i nadzorni odbor. ${ }^{14} \mathrm{U}$ slučaju povrede spomenute zabrane, primjenjuju se odredbe o zabrani konkurencije, a člana uprave mogu pogoditi i osobne sankcije (opoziv, raskid menadžerskog ugovora). Nakon što mu istekne mandat, (bivši) član uprave je i dalje, doduše u ograničenom opsegu, dužan na lojalno ponašanje prema društvu. U tom smislu, on, primjerice, ne smije prisvojiti već započete poslove društva s trećima. U toj činjenici zastupnici spomenutog učenja vide glavnu razliku u odnosu na klasičnu odredbu o zabrani konkurencije: različito od zabrane konkurencije, član uprave svoj privatni, budući poslovni pothvat ne smije temeljiti na prisvajanju poslovne šanse koja izvorno pripada društvu. ${ }^{15}$

\subsection{Sukob interesa prema čl. 248.a ZTD-a}

Izmjenama Zakona o trgovačkim društvima, koje su stupile na snagu 1. XI. 2015. (ZTD, Narodne novine 110/2015), u sustav zaštite društva uvodi se još jedan aspekt sukoba interesa članova uprave. Tako član uprave ne može bez suglasnosti nadzornog odbora sudjelovati u odlučivanju ili sklapanju pravnog posla ako je zastupnik po zakonu, zakonski zastupnik, prokurist ili punomoćnik druge ugovorne strane; ako mu je druga ugovorna strana ili zastupnik po zakonu, zakonski zastupnik, prokurist ili punomoćnik druge ugovorne strane srodnik po krvi u pravoj liniji do bilo kojeg stupnja, a u pobočnoj liniji do drugog stupnja ili mu je bračni drug, izvanbračni drug ili srodnik po tazbini do drugog stupnja, bez obzira na to je li brak prestao ili

14 Fleischer,H.,„GelösteundungelösteProblemedergesellschaftsrechtlichen Geschäftschancenlehre“, $N Z G, 21$ (2003.), str. 985. i dalje. Usp. Jakob, D., „Erfindungen eines Gesellschafters oder GesellschafterGeschäftsführers im Geschäftsbereich der GmbH“, DStR, 21 (2000.), str. 1123.

15 Ibid. 
nije, ili je posvojitelj ili posvojenik druge ugovorne strane, njezina zastupnika po zakonu, zakonskog zastupnika, prokurista ili punomoćnika te ako vezano uz pravni posao o kojem se odlučuje ili se sklapa postoji sukob interesa između člana uprave i društva. Ovom odredbom uređuje se nekoliko pravnih situacija kod kojih se uzima da postoji sukob interesa člana uprave.

Prvo, to je slučaj ako je član uprave zastupnik druge ugovorne strane. Do toga može doći i kod članova uprave sportskog dioničkog društva jer odredbom čl. 38. Zakona o sportu nije isključena mogućnost da ta osoba istovremeno bude primjerice član uprave nekog drugog društva izvan tog sporta ili pak član organa sportskog društva istog sporta ali koji se natječe u drugoj državi. U tom kontekstu, raspravlja se o pitanju tzv. dvostrukih mandata. ${ }^{16}$ Pravni tretman dvostrukih mandata također spada u krug pitanja koja se povezuje sa sukobom interesa, bilo da je riječ o slučaju da je ista osoba član uprave u jednom a član nadzornog odbora u drugom društvu, odnosno da je primjerice član uprave u dva međusobno povezana društva. Čak niti takav slučaj ne bi bio nezamisliv u sportskim okvirima jer naš Zakon o sportu uređuje pitanje ,značajnog sudjelovanja“ samo u sportskim dioničkim društvima istog sporta u našoj državi. ${ }^{17}$

Nositelj dvostrukog mandata kod svojih prosudbi mora uvijek imati u vidu interes onog društva za koje poduzima neku radnju. Zbog ovakve „izolacije“ dužnosti da za oba društva postupa kao uredan i savjestan gospodarstvenik, nositelj se ne može pozvati na to da je povreda dužnosti opravdana dok postupa s dužnom pozornošću u drugom društvu. Osoba koja prihvati obnašati dvostruku funkciju nije automatski zbog sukoba interesa isključena iz glasovanja. U prilog tom zaključku govori i to da za eventualnu štetu članovi uprave odgovaraju solidarno te će u okviru svojih ovlasti koristiti i pojedinačno pravo na nadzor rada ostalih članova uprave. Sukob interesa postoji samo u pojedinačnim slučajevima kada bi neki član uprave došao u situaciju da odlučuje o vlastitoj stvari. Tada nema pravo glasa. To posebice vrijedi za slučaj kada uprava društva majke glasuje na skupštini ovisnog društva i to o opozivu nositelja dvostrukog mandata s funkcije koju obnaša u ovisnom društvu. ${ }^{18}$

Nositelj dvostrukog mandata može se suzdržati od glasovanja kada god time nije ugroženo funkcioniranje uprave kao organa društva. Samo u slučajevima neizbježnog, kontinuiranog i osobito intenzivnog sukoba interesa, član uprave mora dati ostavku. Problem dvostrukih mandata ne postoji kod ugovornog koncerna jer se, prema čl. 493. ZTD-a, upravi ovisnog društva mogu dati i upute koje su štetne za ovisno društvo a služe interesima vladajućeg društva. Sukob interesa zbog dvostrukih mandata u pravilu nije potrebno posebno otkrivati jer je riječ o sukobu apstraktne naravi, a nadzorni odbor je s tom činjenicom morao biti upoznat. U spomenuti krug slučajeva sukoba interesa, kada je član uprave u konkretnom slučaju ujedno i zastupnik druge ugovorne strane, spadaju i slučajevi kada je na

16 Detaljnije otome vidiprimjericeFonk, H.J., ,ZurVertragsgestaltung bei Vorstandsdoppelmandaten“, $N Z G, 10$ (2010.), str. 368. i dalje.

17 Vidi čl. 31. - 36. Zakona o sportu.

18 Hölters, W., Aktiengesetz, 3. Auflage, Vahlen, München, 2017., § 76, Rn. 58. 
tom položaju umjesto člana uprave druga fizička osoba koja je njegov srodnik po krvi u pravoj (do bilo kojeg stupnja) ili pobočnoj liniji (do drugog stupnja), po tazbini (do drugog stupnja), bračni i izvanbračni drug ili je član uprave posvojitelj ili posvojenik druge ugovorne strane (uključivo i njezinih zastupnika).

Drugi važan slučaj kada postoji sukob interesa jest onaj kada, vezano uz pravni posao o kojem se odlučuje ili se sklapa, postoji sukob interesa između člana uprave i društva. Sukob interesa treba promatrati objektivno pa nije od značaja subjektivan dojam člana uprave o tome nalazi li se u sukobu interesa ili ne. Kada su ispunjene pretpostavke, član uprave dužan je obavijestiti ostale članove uprave i nadzorni odbor o sukobu interesa.

Nadalje, za sukob interesa nije dostatno da postoji apstraktna opasnost nastanka takvog sukoba. Sukob interesa mora stvarno postojati jer Zakonodavac uvođenjem odredbe čl. 248. a ZTD-a nije imao za cilj proizvesti učinak da se nadzorni odbor nepotrebno optereti većim brojem prijava članova uprave o postojanju sukoba interesa. Sukob interesa uvijek uključuje element neizvjesnosti jer jednostavno nema mjesta pretpostavci da bi član uprave donio odluku suprotnu interesu društva. To u prvom redu znači da mora nastupiti konkretan sukob interesa koji nije manjeg značaja. Stoga, s druge strane, uprava nije dužna obavijestiti nadzorni odbor o postojanju sukoba interesa koji je manjeg značaja ili kad je riječ o apstraktnom sukobu interesa. Nema dužnosti obavještavanja ako nadzorni odbor i uprava već znaju ili moraju znati za postojanje sukoba interesa.

Zakon u odredbi čl. 248.a, st. 3. predviđa dužnost obavještavanja ostalih članova uprave i nadzornog odbora o postojanju sukoba interesa uz dužnost navođenja svih činjenica od značaja, ali dalje ne navodi kakav će biti daljnji postupak po tom pitanju. Može se zaključiti da će sada nadzorni odbor, postupajući s dužnom pozornošću, ispitati sve relevantne činjenice za donošenje meritorne odluke o tome postoji li sukob interesa.

Za slučaj da član uprave ne postupi po svojoj dužnosti društvo može od njega tražiti da mu nadoknadi time pričinjenu štetu, a alternativno, društvo može tražiti od člana uprave da dopusti da se poslovi koje je sklopio za svoj račun smatraju poslovima sklopljenima za račun društva, a da iz poslova koje je sklopio za tuđi račun prenese društvu ono što je za to primio, odnosno da mu ustupi zahtjev za naplatu (čl. 248.a st. 3. u svezi s čl. 248. st. 2. i 3. ZTD-a).

Zahtjevi društva koje tada zastupa nadzorni odbor zastaruju u roku od tri mjeseca od kada su ostali članovi uprave i članovi nadzornoga odbora saznali za radnju povodom koje se može tražiti nadoknada štete. Zahtjevi zastaruju u svakom slučaju, bez obzira na saznanje za radnju, u roku od pet godina od kada je radnja učinjena. 


\subsection{Sporedne djelatnosti članova uprave izvan sportskog dioničkog društva}

Postavlja se pitanje smije li član uprave obavljati i neke sporedne djelatnosti izvan radnog vremena. Za takve poslove članovima uprave u praksi ne ostaje vremena niti prostora, osim kad je to dodatni angažman u nekom od povezanih društava. U većem dijelu, obavljanje tih poslova već je onemogućeno odredbom o zabrani konkurencije. U svemu ostalom potrebno je u konkretnom slučaju ispitati je li i tu riječ o sukobu interesa. Nije za tu procjenu ključna okolnost da se za taj posao prima naknada ili da se sporedna djelatnost obavlja za vrijeme radnog vremena. Čak i posao koji se radi besplatno ili u slobodno vrijeme može dovesti do dužnosti obavještavanja zbog mogućeg sukoba interesa. ${ }^{19} \mathrm{Tu}$ ne spadaju aktivnosti koje služe razonodi kao što su sport i različiti hobiji. Čak i upravljanje vlastitom imovinom može predstavljati sporednu djelatnost koju mora odobriti nadzorni odbor. Pozitivna ili negativna odluka nadzornog odbora ovisi o tome predstavlja li obavljanje tog posla ponašanje koje je suprotno interesu društva. Suglasnost neće biti dana ako članu uprave ta sporedna djelatnost oduzima previše vremena ili, primjerice, ako je time ugrožen ugled društva odnosno ako se član uprave zbog tog angažmana našao u sukobu interesa. Nema sukoba interesa ako primjerice član uprave sudjeluje u radu strukovnih udruženja, održava predavanja ili je nositelj neke počasne funkcije. Nadzorni odbor može ograničiti odobrenje koje daje članu uprave kako u pogledu trajanja tako i prema opsegu, odnosno sadržaju.

\section{UREĐENJE SUKOBA INTERESA U KODEKSU KORPORATIVNOG UPRAVLJANJA}

Kodeks korporativnog upravljanja trgovačkim društvima u kojima Republika Hrvatska ima dionice ili udjele (u daljnjem tekstu: Kodeks) ${ }^{20}$ predstavlja zbir načela poslovnog profesionalnog ponašanja i dobrih običaja kojima se jača korporativna i vlasnička odgovornost provođenjem standarda ponašanja u svrhu postizanja dobrobiti za sve sudionike. Nema prepreka da se barem neka od tih pravila ne ugrade u statute sportskih dioničkih društava kao i u poslovnike o radu uprava tih društava bilo izričitim navođenjem pojedinih pravila ili pozivanjem na primjenu Kodeksa. Također, spomenuta pravila moguće je ugraditi i u tekst menadžerskih ugovora koje članovi uprave sklapaju sa sportskim dioničkim društvima. Naime, pokazalo se da zbog komercijalizacije sporta pitanje „dobrog upravljanja“ profesionalnim sportskim klubovima postaje sve značajnije. ${ }^{21}$

19 Tako Bachmann, G. u: Kremer T. et al., Deutscher Corporate Governance Kodex, 6. Auflage, 2016., Rn. 1132.

20 Odluka i Kodeks objavljeni u Narodnim novinama, br. 132/2017.

${ }^{21}$ Akšamović, D., Pravo sporta u Hrvatskoj - aktualna pitanja i dvojbe, dostupno na https: //www. ceeol.com/search/gray-literature-detail?id=575155, str. 10, pregledano 15. I. 2018. 
Aktualna verzija našeg Kodeksa znatno je kraća od prethodne (u nastavku: Kodeks 2010) ${ }^{22}$ pa za potrebe rada treba usporedno analizirati obje. Tako se u poglavlju V. Kodeksa navodi da trgovačka društva trebaju imati funkcionalnu upravu čiji broj članova i sastav odgovara potrebama i financijskim mogućnostima trgovačkog društva. Nadalje, članovi uprave ne smiju biti ni u kakvom sukobu interesa bilo u smislu važećih propisa bilo u smislu sukoba interesa trgovačkog društva i osobnog interesa, koji bi doveo u pitanje njihovo upravljanje trgovačkim društvom i donošenje objektivnih i neovisnih odluka na dobrobit trgovačkog društva. Naposljetku, članovi uprave ne smiju donositi odluke na temelju osobnih interesa ili interesa osoba s kojima su povezani.

Sukob interesa znatno je detaljnije bio uređen Kodeksom 2010. Tako se, primjerice, predviđala zabrana korištenja povlaštenih informacija, koja se, između ostalog, odnosi i na članove uprave, kao i na sve osobe koje se s obzirom na svoje pozicije, u društvu i izvan društva, smatraju osobama kojima su dostupne povlaštene informacije. ${ }^{23}$ Uprava je dužna uvijek djelovati isključivo u korist društva i dioničara, vodeći računa o interesima radnika i šire zajednice, s ciljem povećanja vrijednosti imovine društva. Internim pravilima postupanja valja razraditi poslove uprave, kako bi se razjasnile ovlasti i dužnosti. Spomenuti akt treba, između ostalog, uključivati pravila za rješavanje sukoba interesa. ${ }^{24}$

Članovi uprave trebaju biti izvan sukoba interesa, a sukob interesa postoji kod člana uprave koji nije neutralan u odnosu na predmet odlučivanja te može utjecati na donošenje odluke na temelju interesa koji se razlikuju od interesa društva. Članovi uprave ne smiju donositi odluke na temelju osobnih interesa ili na temelju interesa osoba s kojima imaju bliske odnose, a svi poslovi u kojima sudjeluju članovi uprave ili s njima povezane osobe i društvo ili s njim povezane osobe, trebaju biti na tržišnoj osnovi i trebaju biti jasno navedeni u izvješćima društva. Takve poslove također mora potvrditi neovisna procjena od strane stručnih osoba koje su nezavisne u odnosu na sudionike konkretnog posla, a zainteresirani članovi uprave moraju ishoditi prethodnu suglasnost nadzornog odbora ili drugog ovlaštenog organa društva. ${ }^{25}$ Iz izričaja da ,... svi poslovi... trebaju biti na tržišnoj osnovi“ proizlazi da to nije samo preporuka već da je tu riječ o zahtjevu koji neizravno proizlazi iz dužnosti članova uprave na lojalno ponašanje prema društvu. Za poslove koje članovi uprave sklapaju sa samim sobom odnosno za svaki pravni posao koje oni sklope s društvom općenito vrijedi pravilo da bi takav posao, pod jednakim uvjetima, društvo sklopilo i s nekom trećom osobom koja nije član uprave društva.

Članovi uprave ne smiju, za svoj ili tuđi račun, osobno ili putem trećih osoba konkurirati društvu, a također ne smiju imati značajan udio u društvima koja se mogu smatrati konkurentskima društvu. Nadalje, za članstvo u nadzornim odborima

22 Kodeks korporativnog upravljanja trgovačkim društvima u kojima Republika Hrvatska ima dionice ili udjele, Narodne novine br. 112/2010.

23 V. čl. 2.8. Kodeksa 2010.

24 Vidi. čl. 5.3. i dalje Kodeksa 2010.

25 Vidi čl. 5.5.1. i čl. 5. 5.1.1. Kodeksa 2010. 
drugih društava, član uprave treba dobiti prethodnu suglasnost nadzornog odbora svojeg društva, s tim da član uprave ne smije istovremeno biti član nadzornog odbora u više od 3 društva. ${ }^{26}$

Iz svega navedenog proizlazi da je Kodeks 2010 sveobuhvatno uredio materiju sukoba interesa. Ne bi vrijedio zaključak da je tu uvijek riječ o nepotrebnim ponavljanjima odredaba Zakona o trgovačkim društvima jer Kodeks 2010, između ostalog, daje i definiciju sukoba interesa koju ne nalazimo u aktualnoj verziji Kodeksa niti u ZTD-u.

Zakon o trgovačkim društvima s posljednjom izmjenom kojom uvodi odredbu o sukobu interesa sada na potpuniji način uređuje dužnost člana uprave za obavještavanjem ostalih članova tog organa te nadzornog odbora o sukobu interesa. Do spomenute izmjene pitanje sukoba interesa bilo je uređeno čl. 248, 249, 252. i 268. ZTD-a.

Zabrana da se pri odlučivanju član uprave ravna prema vlastitim interesima vrijedi samo dok mu traje mandat. Sklapa li član uprave pravni posao s društvom, društvo tada zastupa nadzorni odbor. S druge strane, kada član uprave pregovara o uvjetima svog menadžerskog ugovora, apsolutno smije slijediti vlastiti interes dok god nije prešao granicu ravnoteže interesa ugovornih strana. Kada uprava donosi odluke iz područja poslovodstva, član uprave koji je u sukobu interesa treba tu okolnost otkriti ostalim članovima uprave i nadzornom odboru te se suzdržati od glasovanja.

\section{ZAKLJUČAK}

Sukob interesa članova uprave sportskih dioničkih društava postoji kod člana uprave koji nije neutralan u odnosu na predmet odlučivanja te može utjecati na donošenje odluke na temelju interesa koji se razlikuju od interesa društva. Zakon o sprečavanju sukoba interesa sukob interesa definira kao situaciju u kojoj privatni interes dužnosnika utječe, ili se osnovano može smatrati da utječe, ili može utjecati na njegovu nepristranost u obavljanju javne dužnosti.

Član uprave ne može bez suglasnosti nadzornog odbora sudjelovati u odlučivanju ili sklapanju pravnog posla ako je zastupnik po zakonu, zakonski zastupnik, prokurist ili punomoćnik druge ugovorne strane, ili je u toj poziciji neka od njemu bliskih osoba. Nadalje, član uprave ne može sudjelovati u odlučivanju ako vezano uz pravni posao o kojem se odlučuje ili se sklapa postoji sukob interesa između člana uprave i društva.

Ako član uprave postupi protivno toj zabrani, društvo može od njega tražiti da mu nadoknadi time pričinjenu štetu, a umjesto toga društvo može tražiti od člana uprave da dopusti da se poslovi koje je sklopio za svoj račun smatraju poslovima sklopljenima za račun društva, a da iz poslova koje je sklopio za tuđi račun prenese

26 Vidi čl. 5.5.1.2. i 5.5.1.3. Kodeksa 2010. 
društvu ono što je za to primio, odnosno da mu ustupi zahtjev za naplatu onoga što bi trebalo da primi.

Sukob interesa treba promatrati objektivno pa nije od značaja subjektivan dojam člana uprave o tome nalazi li se u sukoba interesa ili ne. Kada su ispunjene pretpostavke, član uprave dužan je obavijestiti ostale članove uprave i nadzorni odbor o sukobu interesa.

Nadalje, za sukob interesa nije dostatno da postoji apstraktna opasnost nastanka takvog sukoba. Sukob interesa mora stvarno postojati jer Zakonodavac uvođenjem odredbe čl. 248.a ZTD-a nije imao za cilj proizvesti učinak da se nadzorni odbor optereti većim brojem prijava o postojanju sukoba interesa članova uprave. Sukob interesa uvijek uključuje element neizvjesnosti jer jednostavno nema mjesta pretpostavci da bi član uprave donio odluku suprotnu interesu društva. To u prvom redu znači da mora nastupiti konkretan sukob interesa koji nije manjeg značaja. Stoga, s druge strane, uprava nije dužna obavijestiti nadzorni odbor o postojanju sukoba interesa koji je manjeg značaja ili kad je riječ o apstraktnom sukobu interesa. Nema dužnosti obavještavanja ako nadzorni odbor i uprava već znaju ili moraju znati za postojanje sukoba interesa.

Ne traži se neki poseban stupanj težine (ozbiljnosti) sukoba interesa. Taj prag ozbiljnosti ne smije se postaviti previsoko jer bi to dovelo do situacije da bi dužnost članova uprave na otkrivanje sukoba interesa postojala samo u krajnjim slučajevima. Primjerice, ako je sukob interesa takvog značaja da taj član uprave ne samo da nema pravo glasa nego ne smije niti prisustvovati sjednici na kojoj se odlučuje o pitanju u svezi s kojim postoji sukob interesa. Neke naznake o tome što bi sve spadalo u sukob interesa možemo pronaći i u drugim propisima, primjerice i u čl. 24. Zakona o općem upravnom postupku.

\section{THE CONFLICT OF INTEREST OF THE MEMBERS OF THE BOARD OF SPORTS PUBLIC LIMITED COMPANIES}

The conflict of interest of the members of the board of sports public limited companies exists with a member of the board who is not neutral in relation to the subject of the decision and may influence the decision-making process based on interests that differ from the interests of the company. The Law on the Prevention of Conflict of Interest defines a conflict of interest as a situation in which a private interest of an official may affect his impartiality in performing public duties.

The conflict of interest should be viewed objectively, so the subjective impression of a member of the board whether there is a conflict of interest is not relevant. When the required preconditions are met, the board member is obliged to notify the other members of the board and the supervisory board of the conflict of interest.

Further, there is no real conflict of interest in the case when only putative conflict of interest exists. Conflict of interest always involves an element of uncertainty because there is simply no room for a presumption that a member of the board of directors will make a decision contrary to the interests of the company. In the first place, this means that there must be a concrete conflict of 
interest which is not of minor importance. Therefore, on the other hand, the board is not obliged to notify the supervisory board about the existence of conflict of interest which is of lesser importance or when it comes to an abstract conflict of interest.

There is no duty to notify if the supervisory board and the management already know or need to know about the existence of conflicts of interest.

No special level of difficulty (severity) of conflict of interest is required. This threshold of seriousness should not be too high, as this would lead to a situation in which the task of the board members to detect conflicts of interest would only exist in the extreme cases. Some indications of what would fall into conflict of interest can be found in other regulations, for example in the Law on General Administrative Procedure.

Key words: public limited company, the board, conflict of interests, ban on competition, corporate governance code 